\title{
Effect of Different Number of Perforations in Modified Atmosphere Packaging on Postharvest Life of Capsicum (Capsicum annuum longum)
}

\author{
Sujata Aryal'*, Smriti Dhakal', Prakash Khanal'², Babi Basnet ${ }^{3}$, Arvind Srivastava ${ }^{4}$ \\ ${ }^{1}$ Nepal Polytechnic Institute, Bharatpur, Chitwan, Nepal \\ ${ }^{2}$ Institute of Agriculture and Animal Science, Prithu Technical College, Lamahi, Dang Deukhuri, Nepal \\ ${ }^{3}$ Institute of Agriculture and Animal Science, Midwest Academy and Research Institute \\ College of Live Sciences, Tulsipur, Dang, Nepal \\ ${ }^{4}$ Agriculture and Forestry University, Rampur, Chitwan, Nepal \\ *Author for Correspondence: Email-sujataaryal001@gmail.com \\ Orcid id: https://orcid.org/0000-0001-8112-7377
}

Received: 20 October 2020/Accepted: 25 November 2020

URL:https://doi.org/10.38112/agw.2020.v08i02.010

\begin{abstract}
Modified atmosphere packaging (MAP) with the appropriate number of perforations reduces the postharvest loss of capsicum by maintaining a suitable environment inside the package. The research was conducted from 1st August to 11th August, 2018 at the horticulture laboratory of Nepal Polytechnic Institute, Chitwan to investigate the effect of the different number of perforations in modified atmosphere packaging on postharvest life of capsicum. The experiment was laid out in Complete Randomized Design with 4 replications and 6 treatments. Freshly harvested Big Mama 3 variety was packed in 50 micron Low-Density Polyethylene (LDPE) bag with different numbers of perforations and kept in ambient condition $\left(28 \pm 5{ }^{\circ} \mathrm{C}\right.$ and $\left.80 \pm 10 \% \mathrm{RH}\right)$. The six treatments with different numbers of perforations were: T1- MAP without perforations, T2- MAP with 4 perforations, T3- MAP with 8 perforations, T4- MAP with 12 perforations, T5- MAP with16 perforations and T6- open tray. The result showed significant effects in all the observed parameters. T6 recorded the highest total soluble solids (5.40 Brix) and physiological loss in weight on 3rd, 5th, 7th, 9th and 11 th days with $6.52 \%, 10.12 \%, 12.45 \%, 16.17 \%$ and $20.15 \%$ respectively.Further, T5 recorded the highest shelf life (11.16 days) and vitamin C retention $(52.59 \mathrm{mg} / 100 \mathrm{~g})$. Similarly, T1 recorded the highest titratable acidity $(0.22 \%)$. Thus at ambient room condition, it is suggested to store capsicum at MAP with 16 perforations as it gives higher shelf life and vitamin $\mathrm{C}$ retention.
\end{abstract}

Keywords: Ambient, capsicum, perforations, open tray, shelf life

\section{Introduction}

Capsicum (Capsicum annuum longum) commonly known as bell pepper/sweet pepper belongs to the family Solanaceae. In Nepal, nowadays it is considered a high-value crop. It is getting popularity due to its delicious taste and pleasant flavor. In Nepal, capsicum was cultivated on 1,261 hectares of land in the period 2018/19 with the production of 13,255 metric tonnes (MoALD, 2020). Similarly in Chitwan, capsicum was cultivated on 122 hectares of land with the production of 1,150 metric tonnes in the period 2018/19 (MoALD, 2020).

One of the major problems in the production and marketing of fresh produce is a decrease in shelf life and quality of produce (Hussein et al., 2015). Even after harvesting, there is a continuation of life process due to on-going metabolic activities including respiration and ripening that continue until senescence and death in all vegetables and fruits (Irtwange, 2006; Sandhya, 2010). Undesirable changes in the quality of harvested produce like changes in color, texture and nutritive value are caused by such biological changes that occur after harvesting (Kader, 2005). Different post-harvest technologies have been introduced to reduce the postharvest loss of produce. Modified Atmosphere Packaging (MAP) is also one of the cost-effective post-harvest technology. Modified Atmosphere Packaging (MAP) refers to the storage of fresh produce in plastic film which causes alteration of the gaseous environment by decreasing the $\mathrm{O}_{2}$ and increasing $\mathrm{CO}_{2}$ level around the produce. But the atmosphere created by 
traditional MAP during storage is not sufficient to maintain shelf life and quality of the fresh produce for a long time (Mahajan et al., 2008; Mangaraj et al., 2009; Sandhya, 2010). Thus the use of perforations in MAP can be the best alternative to overcome the limitations of traditional MAP (Rodriguez-Aguilera and Oliveira, 2009; Oliveira et al., 2012a). To regulate the gas and water vapour exchange rates of fresh produce, perforation in the MAP involves the use of single or multiple perforations on polymeric films (Raid et al., 2002; Mahajan et al., 2008). The risk of anaerobiosis and microbial growth associated with moisture condensations due to fluctuating temperature is reduced by the addition of perforation in the MAP (Fonseca et al., 2000). The addition of perforation on MAP helps to control both respiration as well as transpiration through the adjustment of gases and water vapor (Briassoulis et al., 2013). Several authors have noted the beneficial impacts of perforations to create a desirable and safe modified atmosphere for produce (Gonzalez et al., 2008; Pandey and Goswami, 2012).

After harvest capsicum becomes excessive soft due to water loss which leads to shriveling, wilting, pathogenic disorder and finally the quality and acceptance of the produce are reduced (Rao et al., 2011). Proper postharvest handling and storage methods are essential to maintain the acceptable quality and extend market life. Capsicum may be available out of season and shipped to a distant consumer market with high standard quality if proper postharvest packaging is adopted which also ensures the economic safety of farmers. Although MAP is considered as the best packaging material for capsicum, in the ambient condition it is non-effective as it creates barriers for heat and gas exchange. So perforation should be made for proper air exchange. In the context of developing countries like Nepal, where the socio-economic condition of farmers is not feasible in adopting high-cost technologies, perforations mediated MAP can be the best alternative. Thus this research was conducted to evaluate the performance of perforated MAP on postharvest life of capsicum and determine the suitable number of perforations in MAP for capsicum at ambient room condition.

\section{Materials and Methods}

\section{Experimental site}

The experiment was carried out in the Horticultural Laboratory of Nepal Polytechnic Institute, Bharatpur-11 Chitwan, Nepal from 1st August, 2018 to 11th August, 2018. Geographically, it is located at $27.69^{\circ} \mathrm{N}$ latitude, 84 . $44^{\circ} \mathrm{E}$ longitude and an altitude about 256 meters above sea level.

\section{Meteorological data}

The temperature and relative humidity of the storage room were recorded through a hygrometer Figure 1.

\section{Experimental materials, design and treatments}

The experiment was laid out in Complete Randomized Design (CRD) with four replications having 6 treatments in each replication. First of all, freshly harvested Big Mama 3 variety of capsicum was collected from the wholesaler and brought to the horticultural laboratory. Capsicum was sorted out to remove the pest affected, over matured and damaged ones. Low-Density Polyethylene (LDPE) of 50 micron thickness was used as packaging materials with different numbers of perforations (Table 1). In LDPE packets an area of $30 \mathrm{~cm} \times 35 \mathrm{~cm}$ perforations (having $6 \mathrm{~mm}$ diameter) was made with an ordinary punching machine. One $\mathrm{kg}$ of capsicum was maintained in each replication. Then the packets (MAP'S) were kept in ambient storage $\left(28 \pm 5{ }^{\circ} \mathrm{C}\right.$ and $\left.80 \pm 10 \% \mathrm{RH}\right)$. The storage room had sufficient ventilation for air exchange.

\section{Observation}

\section{Physiological loss in weight (PLW)}

Equal quantities of capsicum in each treatment were selected as samples. They were first weighted at the time of storage (initial weight) and the alternate day afterward until the last day of the experiment. PLW was calculated by:

$$
\text { PLW \% }=\frac{\text { Initial weight }- \text { Final weight }}{\text { Initial weight }} \times 100 \%
$$

\section{Shelf life of Capsicum}

Shelf life was determined by up to $50 \%$ acceptability of fruits in each replication. Capsicum was judged on daily observation and discarded after less than $50 \%$ acceptability.

\section{Total soluble solids (TSS)}

TSS in Brix was determined by using a hand refractometer on the first and the last day of storage.

\section{Titratable acidity (TA)}

TA was determined by titration of diluted capsicum juice with few drops of phenolphthalein against base $(0.1 \% \mathrm{NaOH})$ solution. TA was calculated on the first and the last day of storage by the formula: 
$\mathrm{TA}(\%)=$

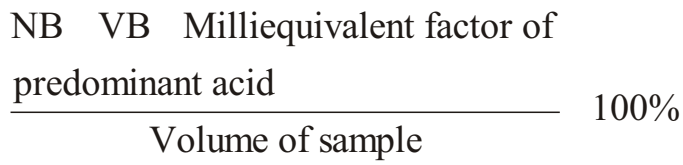

Where, $\mathrm{NB}=$ Normality of base $(\mathrm{NaOH})$

$\mathrm{VB}=$ Volume of base $(\mathrm{NaOH})$

Milliequivalent factor of predominant acid i.e. malic acid is 0.067

\section{Vitamin C}

Vitamin $\mathrm{C}$ was measured on the first and last day of storage as per the reference from Sadasivam and Manickam (2005). Vitamin C content of capsicum juicewas calculated by:

Vitamin C $(\mathrm{mg} / 100 \mathrm{~g})=$

$$
\left(\frac{0.5 \mathrm{mg}}{\mathrm{V} 1 \mathrm{ml}}\right) \times\left(\frac{\mathrm{V} 2 \mathrm{ml}}{5 \mathrm{ml}}\right) \times\left(\frac{100 \mathrm{ml}}{\text { weight of the sample }}\right) \times 100
$$

Where, V1= amount of dye consumed during the titration

$\mathrm{V} 2$ = amount of dye consumed when the supernatant was titrated with $4 \%$ oxalic acid

\section{Statistical analysis}

The recorded data were analyzed by Genstat software. Data was subjected to analysis of variance (ANOVA) to evaluate the significant treatment effects. The significant differences between treatments were determined using Duncan's Multiple Range Test (DMRT). The treatment means were compared by the Least Significant Difference (LSD) test at 5\%(Gomez and Gomez, 1984).

\section{Results and Discussions}

\section{Physiological loss in weight (PLW)}

Statistically, the different number of perforations in the MAP showed significant effects on physiological loss in weight (PLW) recorded on the 3rd, 5th, 7th, 9th and 11 th days of storage (Table 2). T6 (open tray) recorded the highest PLW on the 3rd, 5th, 7th, 9th and 11th days of storage with $6.52 \%, 10.12 \%, 12.45 \%, 16.17 \%$ and $20.17 \%$ respectively. T1 (MAP without perforations) recorded the lowest PLW on the 3rd, 5th, 7th, 9th and 11th days with the value $0.17 \%, 0.27 \%, 0.52 \%, 0.65 \%$ and $1.15 \%$ respectively. The highest PLW at T6 might be because there was no barrier to check the transpiration loss of water. Similarly, after T6, the PLW was more at MAP with perforations than at MAP without perforations (Table 2). It is because perforations increase permeability which influences the respiration and transpiration rates (Panta and Khanal, 2018). Further, Panta and Khanal (2018) on cilantro also noted the highest PLW from openly placed while the lowestfrom the MAP without perforation. Similarly, Grewal et al. (2017) on green chilli also noted a low PLWfromMAP without perforations than fromMAP with perforations. Further, the PLW increased with the increase in storage time in all treatments (Table 2). It is due to the transpiration and respiration process which caused the continuous loss of moisture (Nath et al., 2011).

Figure 1: Temperature and relative humidity of the experimental room.

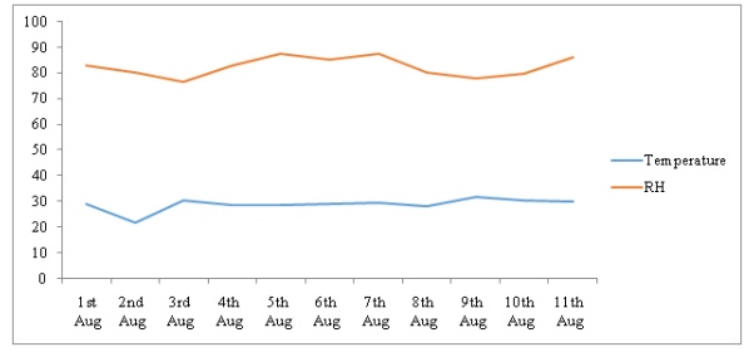

\section{Shelf life and Total soluble solids (TSS)}

Data in Table 3 revealed that the different number of perforations in MAP showed significant results on shelf life and total soluble solids (TSS). Shelf life varied from 6.25 days to 11.16 days. T5 ( MAP with 16 perforations) showed the highest shelf life (11.16 days) followed by 9.50 days at T4 (MAP with12 perforations). T3 and T4 behaved equally without any significant differences among each other on shelf life. T6 (open tray) recorded the lowest shelf life (6.25 days). The increased shelf life in other treatments than at the open tray might be because polyethylene plastic provides a beneficial modified atmosphere, protects products from adverse conditions, mechanical damage and reduces moisture loss (Basel et al., 2002). Another reason might be a decrease in aerobic spoilage microorganisms with a reduced level of $\mathrm{O}_{2}$ in MAP as compared to open tray (Alejandra Rojas-Grau et al., 2009). Further, the MAP with perforations showed more shelf life than in MAP without perforations (Table 3). It might be because MAP without perforation causes condensation of water in the surface of fruits, anaerobic conditions and breakdown of enzymes during storages that enhances the growth of microorganism (Kaur et al., 2014). Rahman et al. (2012) on green chilli also recorded more shelf life, freshness and best acceptance of the product with perforations. Further, Nath et al. (2015) on tomato and Paudel et al.(2019) on mandarin noted an increase in the shelf life with perforations. 
The TSS of capsicum kept in the open tray increased while the TSS of capsicum packed in MAP decreased after storage. The highest TSS (5.40 Brix) was observed at T6 (open tray) followed by 3.15 Brix at T5 (MAP with 16 perforations). T1 and T2 behaved equally without any significant differences among each other on TSS. Similarly, T3 and T4 also behaved equally without any significant differences among each other on TSS. T3 (MAP with 8 perforations) recorded the lowest TSS (2.17 Brix). Bhattarai and Gautam (2006) stated that water loss leads to a higher concentration of sugar in fruits during storage. Further, moisture loss, hydrolysis of polysaccharides and conversion of juice as a result of degradation contribute towards the increase in TSS during storage (Mir et al., 2018). Until the experiment, the more water or moisture loss and degradation occurred at T6 (open tray) as compared to other treatments so T6 might have recorded an increase in TSS. Afriyie (2013) on sweet pepper and Akter et al. (2013) on banana also obtained more TSS at unpackaged thanat packaged withperforations and without perforations.

\section{Titratable acidity (TA) and Vitamin C}

Statistically, the different number of perforations in MAP showed a significant result on titratable acidity (TA) and vitamin $\mathrm{C}$ (Table 3). TA was decreased in all the treatments during storage (Table 3 ) it is because the TA is a quantitative measure of organic acids, decreases with the senescence process (Latifah et al, 2013). Although TA was decreased during storage, T1 (MAP without perforation) recorded the highest TA $(0.22 \%)$. T3 and T4 behaved equally without any significant differences among each other on TA. Similarly, T2 and T6 also behaved equally without any significant differences among each other on TA. T6 (open tray) recorded the lowest TA $(0.137 \%)$. Sinha et al. (2019) on tomato also recorded a decrease in the final value of TA, the highest TA at packaged without perforations while the lowest TA at kept in an open pot. Mphahlele et al. (2020) on litchi also recordeda gradual decrease in TA during storage and the highest TA on packaged without perforations.

The vitamin $\mathrm{C}$ decreased during storage than the initial value.Vitamin $\mathrm{C}$ is more in fresh produce but decreases during storage (El-Ishaq and Obirinakem, 2015). Although vitamin $\mathrm{C}$ decrease $\mathrm{D}$ during storage, T5 (MAP with 16 perforations) recorded the highest vitamin $\mathrm{C}$ retention $(52.59 \mathrm{mg} / 100 \mathrm{~g})$. T3 and $\mathrm{T} 4$ behaved equally without any significant differences among each other on vitamin $\mathrm{C}$. The lowest vitamin $\mathrm{C}$ retention $(40.52 \mathrm{mg} / 100 \mathrm{~g}$ ) was recorded at T6 (open tray). Further, more vitamin $\mathrm{C}$ retention was noted at MAP with perforations than at MAP without perforations (Table 3). The more vitamin $\mathrm{C}$ retention at MAP with perforation than at MAP without perforations and open trays is due to the balance created by the amount of entering and escaping gases through perforations (Singh et al., 2014). Rahman et al. (2012) on green chilli and Satar et al. (2019) on sweet pepper also noted a decrease in vitamin $\mathrm{C}$ after storage, the highest vitamin $\mathrm{C}$ retention at packaged with perforations while the lowest at an open one.

Table 1: Treatment details of the experiment:

\begin{tabular}{|c|c|l|}
\hline S.No. & Treatments & Treatments details \\
\hline 1 & T1 & MAP without perforations \\
\hline 2 & T2 & MAP with 4 perforations \\
\hline 3 & T3 & MAP with 8 perforations \\
\hline 4 & T4 & MAP with 12 perforations \\
\hline 5 & T5 & MAP with 16 perforations \\
\hline 6 & T6 & Open tray \\
\hline
\end{tabular}

Table 2:Effect of the different number of perforations in MAP on physiological loss in weight of capsicum :

\begin{tabular}{|c|c|c|c|c|c|c|}
\hline \multirow[t]{2}{*}{ Treatments } & \multirow[t]{2}{*}{ Initial weight (kg) } & \multicolumn{5}{|c|}{ Physiological loss in weight (\%) } \\
\hline & & 3 day & 5 days & 7 days & 9 days & 11 days \\
\hline $\mathrm{T} 1$ & 1.00 & $0.17 \mathrm{e}$ & $0.27 \mathrm{~d}$ & $0.52 \mathrm{e}$ & $0.65 \mathrm{~d}$ & $1.15 \mathrm{e}$ \\
\hline $\mathrm{T} 2$ & 1.00 & $0.45 \mathrm{~d}$ & $0.45 \mathrm{c}$ & $0.77 \mathrm{~d}$ & $3.10 \mathrm{c}$ & $7.52 \mathrm{~d}$ \\
\hline T3 & 1.00 & $0.52 \mathrm{c}$ & $0.47 \mathrm{c}$ & $1.05 \mathrm{c}$ & $4.75 b$ & $10.62 b$ \\
\hline T4 & 1.00 & $0.57 \mathrm{~cd}$ & $0.57 \mathrm{c}$ & $1.07 \mathrm{c}$ & $4.60 \mathrm{~b}$ & $10.65 b$ \\
\hline T5 & 1.00 & $0.70 \mathrm{~b}$ & $0.77 \mathrm{~d}$ & $1.60 \mathrm{~b}$ & $4.57 \mathrm{~b}$ & $9.80 \mathrm{c}$ \\
\hline Grand mean & 1.00 & 1.49 & 2.11 & 2.91 & 5.64 & 9.99 \\
\hline CV $(\%)$ & & 4.50 & 4.30 & 3.10 & 3.20 & 1.10 \\
\hline $\operatorname{LSD}(0.05)$ & & $0.19 * * *$ & $0.27 * * *$ & $0.26^{* * *}$ & $0.54 * * *$ & $0.33 * * *$ \\
\hline
\end{tabular}


Means within the column followed by the same letter do not differ significantly by DMRT at 5\% level of significance, $C V$ : Coefficient of Variation, LSD: Least significant difference and $* * *=$ Very highly significant.

Table 3: Effect of the different number of perforations in MAP on shelf life, TSS, TA and vitamin C of capsicum:

\begin{tabular}{|l|l|l|l|l|l|l|l|}
\hline \multirow{2}{*}{ Treatments } & \multicolumn{2}{|c|}{ Shelf life } & $\begin{array}{c}\text { TSS } \\
\left({ }^{\circ} \text { Brix) }\right.\end{array}$ & & TA (\%) & \multicolumn{3}{c|}{ Vitamin C (mg/100g) } \\
\cline { 2 - 9 } & & $\begin{array}{c}\text { Initial } \\
\text { reading }\end{array}$ & $\begin{array}{c}\text { Final } \\
\text { reading }\end{array}$ & $\begin{array}{c}\text { Initial } \\
\text { reading }\end{array}$ & $\begin{array}{c}\text { Final } \\
\text { reading }\end{array}$ & $\begin{array}{c}\text { Initial } \\
\text { reading }\end{array}$ & \multicolumn{1}{c|}{ Final reading } \\
\hline T1 & $7.50 \mathrm{~d}$ & 4.00 & $2.37 \mathrm{c}$ & 1.61 & $0.22 \mathrm{a}$ & 60.00 & $42.36 \mathrm{~d}$ \\
\hline T2 & $8.50 \mathrm{c}$ & 4.00 & $2.40 \mathrm{c}$ & 1.61 & $0.14 \mathrm{~d}$ & 60.00 & $45.56 \mathrm{c}$ \\
\hline T3 & $9.25 \mathrm{~b}$ & 4.00 & $2.17 \mathrm{~d}$ & 1.61 & $0.16 \mathrm{c}$ & 60.00 & $50.34 \mathrm{~b}$ \\
\hline T4 & $9.50 \mathrm{~b}$ & 4.00 & $2.20 \mathrm{~d}$ & 1.61 & $0.16 \mathrm{c}$ & 60.00 & $50.46 \mathrm{~b}$ \\
\hline T5 & $11.16 \mathrm{a}$ & 4.00 & $3.15 \mathrm{~b}$ & 1.61 & $0.18 \mathrm{~b}$ & 60.00 & $52.59 \mathrm{a}$ \\
\hline T6 & $6.25 \mathrm{e}$ & 4.00 & $5.40 \mathrm{a}$ & 1.61 & $0.13 \mathrm{~d}$ & 60.00 & $40.52 \mathrm{e}$ \\
\hline Grand mean & 8.69 & 4.00 & 2.95 & 1.61 & 0.17 & 60.00 & 46.97 \\
\hline CV (\%) & 2.80 & & 2.80 & & 5.40 & & 0.40 \\
\hline LSD (0.05) & $0.72 * * *$ & & $0.24 * * *$ & & $0.02 * * *$ & & $0.51 * * *$ \\
\hline
\end{tabular}

Means within the column followed by the same letter do not differ significantly by DMRT at 5\% level of significance, $C V$ : Coefficient of Variation, LSD: Least significant difference and $* * *=$ Very highly significant.

\section{Conclusion}

Based on the above results it can be concluded that MAP with 16 perforations showed the maximum shelf life and vitamin $\mathrm{C}$ retention. Capsicum in different perforations remained fresh but with less perforation, there was more accumulation of water drop. So at ambient room condition, it is suggested to pack capsicum in MAP with 16 perforations to reduce the postharvest loss.

\section{Acknowledgment}

We express our warmest appreciation towards the Nepal Polytechnic Institute, Bharatpur, Chitwan, Nepal for providing platform and support.

\section{References}

Afriyie JY. 2013. Effect Of Different Packaging Systems On Quality And Shelf-Life Of Two Sweet Pepper (Capsicum annuum var grossum) Varieties During Storage At Room Temperature. M.Sc. Postharvest Technology Thesis. College of Agriculture and Natural Resources.Kwame Nkrumah University of Science and Technology, Kumasi.

Akter H, Hassan MK, Rabbani MG and Mahmud AA. 2013. Effects of Variety and Postharvest Treatments on Shelf Life and Quality of Banana. Journal of Environmental Science and Natural Resources, 6(2): 163-175.DOI: https://doi.org/10.3329/jesnr.v6i2.22113.

Alejandra Rojas-Garu M, Oms-Oliu G, Soliva- Fortuny R and Martin-Belloso O. 2009. The use of packaging techniques to maintain freshness in fresh cut fruits and vegetables: a review.
International Journal of Food Science and Technology, 44: 875-889.DOI:

https://doi.org/10.1111/j.1365-2621.2009.01911.x

Basel RM, Racicot K and Senecal AG. 2002. Long shelf-life banana storage using MAP storage coupled with post-harvest MCP treatment. In: Annual Meeting and Food Expo-Anaheim, California, USA. pp.15-19.

Bhattarai DR and Gautam DM. 2006. Effects of harvesting method and calcium on postharvest physiology of tomato. Nepal Agriculture Research Journal, 7: 37-41. DOI: https://doi.org/10.3126/narj.v7i0.1864.

Briassoulis D, Mistriotis A, Giannoulis A and Giannopoulos D. 2013. Optimized PLA-based EMAP systems for horticultural produce designed to regulate the targeted in-package

atmosphere. Industrial crops and products, 48: 68-80. DOI:

10.1016/j.indcrop.2013.03.017.

El-Ishaq A and Obirinakem S. 2015. Effect of Temperature and Storage on Vitamin C Content in Fruits Juice. International Journal of Chemical and Biomolecular Science, 1(2): 17-21.

Fonseca SC, Oliveira FA, Lino IB, Brecht JK and Chau KV. 2000. Modelling $\mathrm{O}_{2}$ and $\mathrm{CO}_{2}$ exchange for development of perforation-mediated modified atmosphere packaging. Journal of Food Engineering, 43(1): 9-15. DOI: 10.1016/S0260 - 8774(99)00122-3.

Gomez KA and Gomez AA. 1984. Statistical procedures for agricultural research. 2nd edn. International Rice Research Institute, College, Laguna, pp. 680.

Gonzalez J, Ferrer A, Oria R, and Salvador M L. 2008. Determination of $\mathrm{O}_{2}$ and $\mathrm{CO}_{2}$ transmission rates through microperforated films for modified atmosphere 
packaging of fresh fruits and vegetables. Journal of Food Engineering, $86(2): 120-194 . \quad$ DOI: 10.1016/j.jfoodeng.2007.09.023.

Grewal PR, Singla, M., Kaur, P., Singh, M. and Dr. Kumar, A. 2017. Quality changes in fresh green chillies (Capsicum annuum L) under modified atmospheres. International of Chemical Studies, 5(5): 332-336.

Hussein Z, Caleb OJ, Jacobs K, Manley M and Opara UL. 2015. Effect of perforation-mediated modified atmosphere packaging and storage duration on physicochemical properties and microbial quality of fresh minimally processed 'Acco' pomegranate arils. LWT-Food Science and Technology, 64: 911-918. DOI: http:// dx.doi.org/10.1016/j.lwt.2015.06.040.

Irtwange SV. 2006. Application of modified atmosphere packaging and related technology in postharvest handling of fresh fruits and vegetable. Agricultural Engineering International: The CIGR EJournal, 8: 1-13. https://cigrjournal.org/index.php/Ejounral/article/view/ 691.

Kader AA. (2005). Increasing food availability by reducing postharvest losses of fresh produce. Acta Horticulturae, 682: 2169-2176. DOI: 10.17660/Acta Hortic. 2005.682.296.

Kaur S, Arora N.K, Gill MIS, BooraRS, Mahajan BVC and Dhaliwal HS. 2014. Effect of perforated and non-perforated films onquality and storage of guava fruits. Indian Journal of Horticulture, 71(3): 390-396.

Latifah MN, Abdullah H, Ab Aziz I, Nur A, Bizura H, Fauziah O, Azlan O, Hairiyah M, Talib Y, Zainab Y and Ismail M. 2013. New approaches in improving the quality and safety maintenance of selected minimally processed tropical fruit for market distribution. Acta Horticulturae, 1012(165): 1229-1234. DOI: 10.17660/ActaHortic.2013.1012.165.

Mahajan PV, Rodrigues FAS and Leflaive E. 2008. Analysis of water vapour transmission rate of perforation-mediated modified atmosphere packaging (PM-MAP). Biosystems Engineering, 100(4): 555-561. DOI:

https://doi.org/10.1016/j.biosystemseng.2008.05.008.

Mangaraj S, Goswami TK and Mahajan PV. 2009. Applications of plastic films for modified atmosphere packaging of fruits and vegetables: a review. Food Engineering Reviews,

1: 133-158.DOI: 10.1007/s12393-009-9007-3.

Mir AA, Sood M and Bandral J.D. 2018.Effect of active packaging on quality and shelf life of peach fruits. The Pharma Innovation Journal, 7(4): 1076-1082.

MoALD. 2020. Statistical Information on Nepalese Agriculture, Ministry of Agriculture and Livestock Development (MoALD), Singh Durbar, Kathmandu, Nepal.
Mphahlele RR, Caleb OJ and Ngcobo MEK. 2020. Effects of packaging and duration on quality of minimally processed and unpitted litchi cv. 'Mauritius' under low storage Heliyon, 6(1):e03229.DOI: https://doi.org/10.1016/j.heliyon.2020.e03229.

Nath A, Bagchi B, Verma VK, Rymbai H, Jha AK and Deka BC. 2015. Extension of Shelf Life of Tomato Using $\mathrm{KMnO} 4$ as Ethylene Absorbent. Indian Journal of Hill Farming, 28(1), 77- 80.

Nath A, Deka BC, Singh A, Patel RK, Paul D, Mishra LK and Ojha H. 2011. Extension of shelf life of pear fruits using different packaging materials. Journal of Food Science and Technology, 49(5): 556-563. DOI: 10.1007/s13197-011-0305-4.

Oliveira F, Sousa-Gallaghera MJ, Mahajan PV and Teixeira JA. 2012a. Evaluation of MAP engineering design parameters on quality of fresh-sliced mushrooms. Journal of FoodEngineering, 108: 507-514. DOI:10.1016/j.jfoodeng.2011.09.025

Pandey SK and Goswami TK. 2012. An engineering approach to design perforated and non-perforated modified atmospheric packaging unit for capsicum. Journal of Food Processing

and Technology, 3(11): $187 . \quad$ DOI: 10.4172/2157-7110.1000187.

Panta R and Khanal A. 2018. Effect of Modified Atmospheric Packaging on Postharvest Storage Life of Cilantro (Coriandrum sativum L.) Stored Under Different Conditions. Journal of Horticulture,5(3): 243. DOI:

10.4172/2376-0354.1000243.

Paudel A, Baral D, Acharya H and Dhital M. 2019. Effect of Post-Harvest Dipping and Various Packaging Materials on Quality Traits of Mandarin (Citrus Reticulata Blanco.).Acta

Chemica Malaysia, 3(2): 14-20. DOI:

10.2478/acmy-2019-0007.

Rahman MM, Miaruddin Md, Chowdhury MdGF, Khan MdHH and Matin MA. 2012. Effect of Different Packaging Systems Andchlorination on the Quality Andshelf Life Of Green Chili. Bangladesh Journal of Agricultural. Research, 37(4): 729-736.DOI: 10.3329/bjar.v37i4.14397.

Rao TVR, Gol NB and Shah KK. 2011. Effect of postharvest treatments and storage temperatures on the quality and shelf life of sweet pepper (Capsicum annum L.). Scientia Horticulturae, 132(1): 18-26. DOI: 10.1016/j.scienta.2011.09.032.

Riad G, Brecht J and Chau K. 2002. Perforation-mediated modified atmosphere packaging of sweetcorn. Proc. Fla. State Hort. Soc, 115: 71-75.

Rodriguez-Aguilera R and Oliveira JC. 2009. Review of design engineering methods and applications of active and modified atmosphere packaging systems. Food 
Engineering Review, 1: 66-83. DOI: https://doi.org/10.1007/s12393-009-9001-9.

Sadasivam S and Manickam A. (2005). Biochemical methods. Revised. New Age International (P) Ltd, Publishers. New Delhi.

Sandhya. 2010. Modified atmosphere packaging of fresh produce: Current status and future needs. A review. LWT-Food Science and Technology, 43: 381-392. DOI: https://doi.org/10.1016/j.lwt.2009.05.018

Sattar MdA, Quddus MdA, Rahman MdH, Hossain MdA, Sarker MH and Islam R. 2019. Ostharvest Temperatures and Packaging Materials on Shelf Life and Fruit Quality of Selected Hybrid of Sweet Pepper. Journal of Energy and Natural Resources, 8(4): 137-145. DOI: 10.11648/j.jenr.20190804.12.

Singh R, Giri SK and Kotwaliwale N. 2014. Shelf-life enhancement of green bell pepper (Capsicum annuum L.) under active modified atmosphere storage. Food Packaging and Shelf Life, 1(2): 101-112. DOI: 10.1016/j.fpsl.2014.03.001.

Sinha SR, Singhaz A, Faruquee M, Jiku MdAS, Rahaman MdA, Alam MdA and Kader M.A. 2019. Post-harvest assessment of fruit quality andshelf life of two elite tomato varieties cultivated in Bangladesh. Bulletin of the National Research Centre, 43, Article Number: 185.DOI: https://doi.org/10.1186/s42269-019-0232-5. 